\title{
Diálogos de além-mar: um artigo inédito de José de Alencar
}

\section{Overseas dialogues: a unique article by José de Alencar}

\author{
WILTON JOSÉ MARQUES \\ Universidade Federal de São Carlos - São Carlos - São Paulo - Brasil
}

a

Resumo: O texto apresenta um artigo inédito do escritor romântico brasileiro José de Alencar, publicado em 1851 no jornal Correio Mercantil. Em linhas gerais, o artigo de Alencar é um estudo crítico-biográfico do livro Dores e Flores (1851), do poeta português Augusto Emílio Zalaur.

Palavras-chave: José de Alencar; Artigo inédito; Augusto Emilio Zaluar; Dores e Flores (1851).

\begin{abstract}
The paper presents a unique article of the Brazilian romantic writer José de Alencar, published in 1851 in the newspaper Correio Mercantil. Generally speaking, Alencar's article is a critical-biographical study of the book Aches and Flowers (1851), written by the Portuguese poet Augusto Emilio Zalaur.
\end{abstract}

Keywords: José de Alencar; a unique article; Augusto Emilio Zaluar; Aches and Flowers (1851).

No início de sua longa carreira literária, o futuro romancista romântico José de Alencar escreveu regularmente, entre setembro de 1854 e de julho de 1855 , uma série de folhetins para o jornal Correio Mercantil, importante periódico da imprensa oitocentista brasileira e ao mesmo tempo notoriamente ligado ao ideário político do Partido Liberal. Inserta nas Páginas Menores, seção que fora criada em substituição à temida Pacotilha, ${ }^{2}$ a coluna do jovem Alencar, batizada de Ao correr da pena, tornou-se logo uma das principais atrações do jornal, ocupando, sempre aos domingos, o espaço nobre do rodapé da primeira página. No entanto, o que somente

\footnotetext{
1 Tanto a transcrição do artigo inédito de José de Alencar quanto os eventuais fragmentos de livros e jornais do século XIX aqui reproduzidos tiveram sua ortografia atualizada. No entanto, no que se refere aos demais aspectos expressivos, procurou-se preservá-los tais quais estão nas diversas publicações, sobretudo os que se referem à pontuação, ainda que, em alguns momentos pontuais, signifique menosprezar as regras atuais.

2 Circulando entre 9 de fevereiro de 1851 e 30 de junho de 1854, a Pacotilha, cujos textos tinham visada irônico-crítica, era o próprio jornal aos domingos e tem sua origem explicada pelo acirramento dos entraves políticos com os conservadores que, naquele momento, estavam no poder. Com a articulação da Conciliação partidária, que em linhas gerais abria a possibilidade de incorporação de alguns membros moderados do Partido Liberal ao Gabinete Conservador, liderado pelo Marques de Paraná, o Correio Mercantil, que defendia a política conciliatória, resolveu acabar com a Pacotilha, substituindo-a pela nova seção Páginas Menores, em 9 de julho de 1854 .
}

alguns poucos críticos literários sabiam, é que na verdade três anos antes de começar a escrever os folhetins de $A o$ correr da pena, o autor já havia estreado na imprensa diária, publicando no mesmo Correio Mercantil um primeiro texto de viés crítico.

Em meados do ano de 1851, depois de formado e estabelecido no Rio de Janeiro como advogado, o jovem Dr. José Martiniano de Alencar publicou um artigo de crítica literária na concorrida, e quase sempre polêmica, seção das "Publicações a pedido" do Correio Mercantil. $\mathrm{O}$ referido artigo, que o advogado novato, como era de praxe, provavelmente pagou para sair nas páginas do jornal liberal, foi publicado em duas partes (30 de julho e 23 de agosto de 1851) e assinado somente na segunda como autoria de "Alencar". Em linhas gerais, o artigo é um longo estudo de cunho crítico-biográfico feito a partir da leitura do livro Dores e flores (1851), do poeta português Augusto Emílio Zalaur.

De saída, a primeira referência encontrada sobre a existência deste texto do jovem Alencar aparece no quinto tomo do Dicionário Bibliográfico Português, de Inocêncio Francisco da Silva, publicado em 1860. No verbete já dedicado ao autor cearense, lê-se que: "depois de formado em 1851, ano em que no Rio de Janeiro se estabeleceu como Advogado, [José de Alencar] há tido parte na redação de várias folhas periódicas, escrevendo 
entre outras no Correio Mercantil do dito ano um artigo crítico-bibliográfico sobre as Poesias de A. Zaluar [...]" (SILVA, 1860, p. 60). Posteriormente, o crítico Manuel Cavalcanti Proença, em "José de Alencar na literatura brasileira", texto que, antes mesmo de virar livro, apareceu como introdução ao primeiro volume da Ficção completa e outros escritos em 1958, afirmou, por sua vez, que: "romancista por excelência, [Alencar] não começou pelo romance, mas pelo jornalismo. É preciso fazer a mão, adquirir o hábito. Em 1851, manda os primeiros artigos para o Correio Mercantil, não apenas sobre literatura, mas sobre política e finanças" (ALENCAR, 1958, p. 20). Foi muito provavelmente a partir desta afirmação de Cavalcanti Proença que um dos biógrafos de Alencar, Raimundo de Menezes, passou a defender a verossímil tese de que o artigo sobre o livro do poeta Augusto Emílio Zaluar teria sido, na verdade, a estreia literária do futuro escritor romântico no jornal liberal:

Romancista por experiência - comenta Cavalcanti Proença - Alencar não começa pelo romance, mas pelo jornalismo. É preciso fazer a mão, adquirir o hábito. É o que lhe acontece. Em 1851, estreia com um estudo crítico sobre as Poesias, de Augusto Emílio Zaluar (português, que, depois de cursar o 1ㅇano de medicina, emigra e se naturaliza brasileiro), no Correio Mercantil (MENEZES, 1977, p. 65).

Neste sentido, e considerando como plausível essa tese defendida por Raimundo de Menezes, sobretudo em função dos indícios apontados, é deveras curioso perceber que, até hoje, este primeiro texto crítico de José de Alencar nunca tenha sido coligido e, portanto, republicado. Em outras palavras, por não constar da fortuna literária do autor, este artigo é, a rigor da palavra, um texto inédito. Sintomaticamente, para além da importância literária da redescoberta em si, tal fato indica o quanto as pesquisas sobre os principais autores brasileiros do século XIX, ou mesmo de séculos anteriores, ainda apresentam lacunas significativas nessa, reconheça-se aqui, difícil tarefa da historiografia literária, notadamente no que se refere à necessidade de se realizar o mapeamento mais detalhado de suas respectivas obras.

Entretanto, antes de apresentar na íntegra este primeiro artigo de José de Alencar na imprensa diária brasileira, talvez seja oportuno, ainda que de modo breve, discutir não somente a estreita relação que o poeta português Augusto Emílio Zaluar acabou por estabelecer com o Correio Mercantil, onde, inclusive, mais tarde trabalharia, como também destacar a surpreendente repercussão que o seu livro Dores e Flores - hoje ilustre desconhecido para leitores e críticos - ao menos conseguiu despertar nas páginas deste mesmo jornal.

\section{O "moço português" e o Correio Mercantil}

Após desembarcar na cidade do Rio de Janeiro em novembro de 1849, o poeta Augusto Emilio Zaluar trabalhou na redação do Correio Mercantil em algum momento impreciso da primeira metade da década de 1850 , talvez, como se mostrará a seguir, a partir do ano de 1853 ou de 1854. De início, sua relação de trabalho com o periódico liberal pode ser comprovada através do seguinte acontecimento: no segundo semestre de 1857, na cidade de Petrópolis, Augusto Zaluar participou direta e ativamente, como redator responsável e com a efetiva colaboração de Quintino Bocaiúva, da fundação de $O$ Paraíba, cujo primeiro número veio à luz em 2 de dezembro de 1857 , data escolhida por ser o dia do aniversário do Imperador D. Pedro II. Além do editorial de abertura de jornal, escrito por Bocaiúva, o primeiro número também trazia um artigo em forma de carta aberta ao próprio Zaluar em que seu autor, o romancista Manuel Antônio de Almeida, fazia uma verdadeira profissão de fé do tipo "mais simpático, mais do século, mais original, mais moderno" que, para ele, era o do jornalista periódico:

Admiro com orgulho e com entusiasmo todas as grandes coisas da época em que vivemos: [...] extasiame a fecundidade da poesia, da história e da literatura moderna, que excederam de uma imensa superioridade tudo quanto produziu o mundo antigo, mas de todos esses lidadores - sábios, industriosos, poetas, historiadores e literatos, o tipo não mais admirável porém mais simpático, mais do século, mais original, mais moderno, é o do jornalista periódico. ${ }^{3}$

No dia seguinte ao lançamento de $O$ Paraíba, foi publicada uma pequena nota nas "Notícias diversas" do Correio Mercantil que, por um lado, desejava "as mais sinceras felicitações e os melhores agouros" ao aparecimento do novo órgão de imprensa e, por outro, informava aos leitores que o Sr. Zaluar havia iniciado "sua vida de jornalista" na folha liberal. Diz a nota:

Vimos ontem o primeiro número do periódico $O$ Paraíba, que o Sr. Augusto Emilio Zaluar acaba de fundar em Petrópolis. Não temos senão que dirigir ao nosso ilustrado colega as mais sinceras felicitações e os melhores agouros. Foi no Correio Mercantil que o Sr. Zaluar começou a sua vida de jornalista; não é o primeiro de nossos irmãos de trabalho que vemos aceitar com empenho a profissão conosco começada e continua-la com brilho e distinção. É, pois, como em causa própria que aplaudimos aquela empresa e que nos interessamos pelo seu bom êxito. ${ }^{4}$

\footnotetext{
ALMEIDA, Manuel Antônio de. "A Zaluar". O Paraíba. Petrópolis, 2 de dezembro de 1857, n. 1, p. 2.

4 Correio Mercantil. Rio de Janeiro, 3 de dezembro de 1857, n. 330, p. 1.
} 
Nessa mesma direção, em 9 de fevereiro de 1862, em artigo publicado no Diário do Rio de Janeiro em homenagem ao mesmo Manuel Antônio de Almeida, que desaparecera no naufrágio do vapor Hermes em janeiro do ano anterior, Augusto Zaluar faz uma menção indireta ao ano em que supostamente teria começado a trabalhar no Correio Mercantil, e cuja redação, para ele, "tem servido de noviciado a tantas inteligências jornalísticas do Brasil". No fragmento abaixo, Zaluar afirma que "há de haver 8 para 9 anos que isso foi", o que, por sua vez, e considerando que o artigo é 1862, remeteria sua entrada no jornal liberal aos anos de 1853 ou 1854:

Foi na redação do Correio Mercantil, nessa redação que tem servido de noviciado a tantas inteligências jornalísticas do Brasil, que conhecemos os Dr. Almeida. Há de haver 8 para 9 anos que isso foi. Quem podia aproximar-se daquela natureza expansiva, daquela imaginação brilhante, daquela afetuosidade leal, sem o idolatrar? Fomos desde então irmãos. Comungando em princípios idênticos, ambos desprotegidos da fortuna e dos homens, se alguma vez nos perdemos momentaneamente de vista, seguindo o caminho de nossos destinos, nunca sofreu tibieza a nossa amizade, nem descremos jamais um do outro. ${ }^{5}$

De fato, além de ter iniciado a vida jornalística no Correio Mercantil e se tornado amigo fraterno - "fomos desde então irmãos" - do autor de Memórias de um sargento de milícias, parece mesmo, ao que tudo indica, que o Sr. Zaluar construiu uma relação muito estreita com a folha liberal. Três meses depois de sua chegada ao país, o jovem poeta português foi homenageado com um soneto de autoria de um certo I. J. Ferreira Maranhense publicado em fevereiro de 1850 na seção das "Publicações a pedido" do Correio Mercantil. O poema, inclusive, foi precedido pelas seguintes palavras: "À chegada a esta corte do jovem poeta o Ilmo. Sr. Augusto Emilio Zaluar". ${ }^{6}$ No mês seguinte, o próprio Ilmo. Sr. Zaluar publicaria na mesma seção das "Publicações a pedido" um poema "Numa ilha americana" -, datado de 10 janeiro de 1850 e que, com alterações pontuais, seria incluído em Dores e Flores. ${ }^{7}$ Referindo-se obviamente ao Brasil, o poeta, na primeira estrofe, assumindo-se como estrangeiro em terra estranha, põe-se então a se indagar:

Onde irei, estrangeiro, neste solo,

Buscar um peito que minh'alma entenda?

Em ludibrio da sorte, e sem conforto,

Errante nesses plainos abrasados

D'América plaga? Quem me acoite

Onde irei procurar? Quem me responda

Aos férvidos suspiros, que me rebentam

Nos magoados sons da rude lira.

Que emudeceu à voz da desventura?

Onde irei, estrangeiro, neste solo,

Buscar um peito que minh'alma entenda? ${ }^{8}$
Além da posterior e fraterna amizade com Manuel Antônio de Almeida, algumas evidências apontam que o "moço português" conseguiu se inserir rapidamente no ambiente intelectual do Rio de Janeiro, estabelecendo outras relações de amizade, notadamente - talvez até por afinidades literário-políticas - com autores ligados àquela folha liberal. Tal hipótese se torna ainda mais factível, quando, por exemplo, leva-se em conta que dos muitos poemas de Dores e Flores, três deles foram dedicados respectivamente ao poeta Antônio Gonçalves Dias, ao jornalista Henrique Cézar Muzzio e, por fim, ao romancista Joaquim Manuel de Macedo. ${ }^{9}$ Naquele momento, os dois primeiros eram funcionários do Correio Mercantil enquanto o terceiro havia publicado ali, na forma de folhetim, o seu terceiro romance - Os dois amores - ao longo do ano de 1848.

De todo modo, para não correr o risco de se aventar a possibilidade de mera coincidência histórica, é igualmente importante constatar que, quando do efetivo lançamento de Dores e Flores, em maio de 1851, tanto o "livro de mimosas poesias" quanto o seu autor português - "o poeta estrangeiro que escolheu as praias brasileiras para lhe darem novas inspirações a seus cantos" - foram literalmente apresentados ao público leitor brasileiro através de uma pequena nota estampada na 13 a Pacotilha do Correio Mercantil, datada de 4 e 5 de maio de 1851:

O Sr. Zaluar, moço português, que se acha atualmente no Rio de Janeiro, acaba de publicar um livro de mimosas poesias, com o título de Dores e Flores.

Seja bem vindo, pois, o poeta estrangeiro que escolheu as praias brasileiras para the darem novas inspirações a seus cantos, e banharem de pungente saudade os seus maviosos carmes. Neste livro, que recomendamos com especialidade às nossas amáveis leitoras, encontrar-se-ão mui variadas e viçosas flores, que nem todas germinaram debaixo do mesmo solo, nem desabrocharam também à claridade dos mesmos astros, mas que podem perfumar todos os sentidos, como essas essências raras do Oriente, que não perdem os aromas ainda que transportadas a diversos climas. ${ }^{10}$

Poucos dias depois desta apresentação oficial ao público brasileiro do "moço português, que se acha atualmente no Rio de Janeiro", o anúncio de venda do

\footnotetext{
ZALUAR. Augusto Emilio. "Transcrição: Manoel Antônio de Almeida". Diário do Rio de Janeiro. Rio de Janeiro, 5 de fevereiro de 1862 , n. 36, p. 2.

6 Correio Mercantil. Rio de Janeiro: 9 de fevereiro de 1850, n. 40, p. 3.

7 ZALUAR, Augusto Emilio. "Numa ilha americana". Correio Mercantil. Rio de Janeiro, 23 de março de 1850 , n. 80, p. 3.

8 Idem, p. 3.

9 Os poemas são respectivamente: "Melancolia", "O tronco isolado" e "Na véspera de publicar este livro". (Cf. ZALUAR, 1851; 49-52; 59-62 e 154-156)

${ }^{10}$ Correio Mercantil. Rio de Janeiro: 4 de maio (domingo) e 5 de maio
} (segunda-feira) de 1851, n. 107, p. 2. 
livro Dores e Flores, sobretudo a partir do dia 15 de maio de 1851, começou a aparecer com razoável frequência, juntamente com outras obras literárias ou não, na página de classificados do Correio Mercantil, sob o título de "Obras em português à venda nesta tipografia". Além das trinta e sete vezes que, entre maio e dezembro de 1851 , este anúncio institucional foi reproduzido, ${ }^{11}$ existem ainda dois outros anúncios exclusivos do livro, ambos publicados no mês de julho. ${ }^{12}$

Além da propaganda do livro em si e antes propriamente do artigo do jovem José de Alencar, que, como já se disse, saiu em duas partes, a primeira em 30 de julho e a segunda em 23 de agosto de 1851, também apareceram, entre junho e julho de 1851, nada menos que três outros textos críticos sobre o livro de Zaluar e, por fim, um poema dedicado a ele. Todos os textos também publicados nas "Publicações a pedido" do Correio Mercantil. O primeiro texto saiu no dia 3 de junho com o título "Dores e Flores poesias do Sr. Augusto E. Zaluar", assinado apenas por A. A. M. ${ }^{13}$ Dez dias depois, em 13 de junho, saiu o segundo texto, de idêntico título, mas com o traço diferencial de que este não trazia identificação de autoria. ${ }^{14}$ No dia 8 de julho, apareceu o terceiro artigo - "O livro do Sr. Zaluar" - assinado apenas por J.. ${ }^{15}$ No dia 18 de julho, F. Rangel publicou um poema - "Os teus carmes" - , datado de 15 de julho. Além de usar versos do próprio Zaluar como epígrafe, o poema de Rangel é antecedido pela seguinte explicação: "Ao ler as poesias - Dores e Flores - do meu amigo Augusto Emilio Zaluar". ${ }^{16}$

Por fim, além dos citados, a repercussão do livro do "moço português" também alcançou alguma ressonância em Portugal, sendo, nesse sentido, corroborada pelo longo artigo de Lopes de Mendonça - "Dores e Flores por Augusto Emilio Zaluar, Rio de Janeiro 1851" - publicado em 21 de janeiro do ano seguinte na Revista de Lisboa e que, mais uma vez, seria republicado nas "Publicações a pedido" do Correio Mercantil no dia 03 de março de $1852 .{ }^{17}$

Enfim, após este rápido e superficial olhar sobre as repercussões do livro de Augusto Emilio Zaluar restrito

\footnotetext{
${ }^{11}$ Em 1851, o primeiro anúncio institucional do Correio Mercantil contendo o livro de Zaluar saiu em 15 de maio e o último em 15 de dezembro. A despeito de o interesse aqui restringir-se apenas ao ano de 1851, Dores e Flores ainda aparece várias vezes anunciado ao longo da década de 1850. Cf. Correio Mercantil. Rio de Janeiro, 15 de maio de 1851, n. 115, p. 4 e 15 de dezembro de 1851, n. 309, p.4.

$12 \mathrm{O}$ texto do anúncio diz o seguinte: "Dores e Flores, poesias de Augusto Emilio Zaluar. Vende-se em todas as lojas já anunciadas, e na de M. Garnier, rua do Ouvidor n, 69: preço $3 \$ 000$ rs". Cf. Correio Mercantil. Rio de Janeiro, 10 de julho de 1851, n. 162, p. 3 e 26 de julho de 1851 , n. 176, p. 4 .

13 Correio Mercantil. Rio de Janeiro, 3 de junho de 1851, n. 131, p. 2.

${ }^{14}$ Correio Mercantil. Rio de Janeiro, 13 de junho de 1851, n. 139, p. 2.

15 Correio Mercantil. Rio de Janeiro: 8 de julho de 1851, n. 160, p. 2.

${ }^{16}$ Correio Mercantil. Rio de Janeiro, 18 de junho de 1851, n. 169, p. 3.

${ }_{17}$ Correio Mercantil. Rio de Janeiro, 3 de março de 1852, n. 63, p. 2-3.
}

apenas e tão somente às páginas do Correio Mercantil, é possível conjecturar aqui que, no mínimo, esta obra poética do "moço português" talvez devesse merecer, por parte da crítica literária, uma leitura mais cuidadosa para, quem sabe, tentar detectar possíveis diálogos textuais com autores locais. Ou ainda talvez, em vista dos indícios levantados, outros eventuais influxos estéticos que, por ventura, Dores e Flores possa ter deixado (se é que deixou?) no universo romântico português e/ou brasileiro.

\section{O artigo do jovem Alencar}

Como já foi dito, o primeiro artigo do jovem Dr. José Martiniano de Alencar no Correio Mercantil sobre o livro Dores e Flores foi publicado em duas partes. E, além de sua linguagem ser permeada, como era de se esperar, por um tom altamente romântico e que, de certa forma, antecipa o estilo de escrita que consagraria o autor na literatura brasileira, o artigo está, por assim dizer, mais próximo de uma híbrida "narrativa crítica" do que propriamente um exercício objetivo de crítica literária. De caráter algo impressionista e ingênuo, inerente à juventude literária do autor, e ao mesmo tempo ancorado na crença romântica que aproximava fatos da vida à obra literária, o texto de José de Alencar, ainda que contenha obviamente uma superficial apreciação crítica de alguns poemas do livro de Augusto Zalaur, é construído através do artifício textual de entremear passagens ficcionalizadas da vida do autor com fragmentos de poemas pinçados à obra. No início do texto, que funciona como uma espécie de pequeno prólogo, Alencar, ao afirmar que Dores e Flores era "ao mesmo tempo o livro do homem e do poeta", propõe-se então a literalmente "contar esta história" que, para ele, "é simples e natural", uma vez que "é o sentir íntimo e suave que perfuma as folhas deste livro, e que se insinua docemente no coração de quem o lê e compreende".

Após este "prólogo", na primeira parte do artigo e em tom crescente, José de Alencar passa então a "narrar" acontecimentos da vida do Zaluar, desde a sua triste partida de Portugal, quando em novembro de 1849 "um navio esfraldava as velas às brisas" e um homem "fitava as últimas sombras da terra, [...] com a lágrima a correr ao longo das faces", às inevitáveis consequências do "desterro, [d]a orfandade, e [d]a decepção", cristalizadas no poema "Ao deixar Portugal". Passando pelo enfrentamento da incerta travessia do oceano gerada pelo "hálito ardente do temporal" e retratada na "triste peripécia de um drama heroico" do poema "Naufrágio", até o momento crucial em que "o navio entrou a barra do Rio de Janeiro" e o poeta, tomado por um "sentimento de angustia", chega na "terra estranha" em que "as saudades da pátria vão de mistura com as ricas harmonias de nossa terra" no poema "Numa Ilha Americana". Para, 
por fim, lançar-se na procura desesperada de "um seio para suas confidências, [de] um amigo para compreendêlo" no poema "Ninguém!", que, inclusive na opinião de Alencar, "se não é a mais bela poesia deste livro e a mais rica de imagens, é de certo a mais íntima e repassada de sentimento".

$\mathrm{Na}$ segunda parte do artigo, o tom do texto fica um pouco mais soturno, pois "ao abalo das grandes dores sucede sempre um desalento". Nesse sentido, como é "na solidão e no isolamento, quando a natureza se harmoniza com este estado de alma" que "apenas se sente um desgosto sem causa, uma mágoa íntima”, José de Alencar ilustra este momento de "ânsia e desespero" do poeta através do poema "Melancolia", que, além de ser dedicado a Gonçalves Dias, é, também na opinião dele, "uma das muitas poesias do livro que não se admiram, mas que se sentem". Insistindo nessa perspectiva, o autor também comenta o poema "O tronco isolado" que "para o vulgar dos homens isso queria dizer apenas uma árvore seca; porém para o poeta havia ali uma ruína do passado em face das realidades do presente".

No entanto, antes de rematar o artigo comentando o último poema do livro, "Meu pai", que, segundo ele, “o que aí está não sei como defini-lo", pois "é uma alma partilhada entre saudade e remorso, que sente necessidade suprema de ouvir o perdão balbuciado pelos lábios do pai”, o jovem José de Alencar, já sendo, por assim dizer, Alencar, isto é, antecipando sua índole de precoce polemista, não deixa de apontar alguns defeitos do livro, criticando com alguma severidade, mesmo sem identificálos, alguns poemas "sem espontaneidade, sem causa", desses que "se fazem por pretexto e por força de vontade" e que, no fundo, seriam resultantes de "momentos de esterilidade, e que esses pensamentos arrancados com esforços são filhos espúrios e sempre degenerados". Nesse sentido, e não se fazendo de rogado, dispara: "se alguma censura houvéssemos de fazer, não seria por certo ao poeta que compôs esses versos, mas ao escritor público que os julgou dignos de publicação". Portanto, assumindo o papel judicativo de crítico literário, Alencar ainda acrescenta: "em tributo à glória do Sr. Zaluar, arrancamos essas flores murchas à sua grinalda de poeta".

Em suma, apesar deste primeiro artigo de José de Alencar no Correio Mercantil ser antes de mais nada um texto de juventude literária, o que explica de antemão a superficialidade crítica, a sua redescoberta torna-se um um fato significativo na medida em que, por um lado, detecta-se o precoce caráter polemista do autor, e, por outro, traz à luz um de seus primeiros exercícios críticos, o que, a despeito do já mais que reconhecido lugar histórico de José de Alencar na literatura brasileira, ao menos contribuirá para o estabelecimento de mais um texto na sua fortuna literária.

\section{Dores e Flores \\ Poesias do Sr. A. E. Zaluar ${ }^{18}$}

Há coisa de alguns meses saiu do prelo um livro, que trouxe por título estas duas palavras: Dores e Flores.

É ao mesmo tempo o livro do homem e do poeta. $\mathrm{O}$ poeta fala a doce linguagem do sentimento, bela, rica, cheia de inspirações e harmonia. O homem apenas se revela a momentos por algum destes gritos partidos do fundo d'alma, por uma queixa balbuciada involuntariamente, por uma palavra cortada sem nexo, caída dos lábios a custo.

É esta duplicidade que mais encanta neste livro; e talvez por causa dela advinha-se entre os cismas e os enlevos da imaginação uma história que parece receosa de trair-se, e que apenas se pressente como uma revelação misteriosa, ou como o eco das últimas palpitações d'alma.

Quero contar esta história: é simples e natural; é o sentir íntimo e suave que perfuma as folhas deste livro, e que se insinua docemente no coração de quem o lê e compreende.

$$
* * *
$$

Em novembro de 1849, um navio esfraldava as velas às brisas, e cortava ao largo; longe, nas extremas do horizonte, descortinavam-se quase a sumir-se as terras de Portugal.

$\mathrm{Na}$ tolda do navio, um homem com o olhar estendido pelo espaço fitava as últimas sombras da terra que se esvaeciam como exalações das águas.

$\mathrm{O}$ que havia de tão triste e solene no olhar deste homem?...

Havia uma última despedida, um adeus extremo; porque esse curto instante em que as terras da pátria vacilavam sobre as águas marcava um termo na história de sua vida; era o derradeiro momento do passado e a primeira hora do desterro.

Isso para o homem; para o poeta havia um desses hinos melancólicos, envoltos de mágoa e saudade, que ora parecem lançar-se trêmulos e vacilantes como um grito abafado de desespero, e ora deslizar-se frouxamente como a lágrima a correr ao longo das faces.

As palavras modestas que servem de epígrafe a esta poesia são sublimes de naturalidades: Ao deixar Portugal. Para quem thes compreende o alcance, elas querem dizer o homem deixando a pátria, o filho abandonando a família, o mancebo perdendo o amor e as ilusões; isto é, o desterro, a orfandade, e a decepção.

Três amores santos, três grandes cordas do coração que estalavam convulsivamente nesta alma de fortes e poderosas impressões.

Compreende-se isto; mas para senti-lo é preciso ouvir o poema:

\footnotetext{
${ }^{18}$ ALENCAR. José de. "Dores e Flores - Poesias do Sr. A. E. Zaluar". Correio Mercantil: Rio de Janeiro, 30 de julho de 1851, n. 179, p. 2.
} 
Como um cisne moribundo

Nas verdes ribas das Eurotas,

Ergue do seio profundo

As melodias ignotas,

Em sons de amor abrasados,

Partidos de mil gemidos,

Frouxamente desprendidos

Em suspiros magoados;

Assim meu extremo canto

Débil e fraco lamento,

Volve-me a vida um momento,

Que n'outro m'a rouba o pranto;

Tece de pálidas flores

A derradeira capela,

Preso com volta singela

À lira dos meus amores.

Adeus extremo! arrancado

D’alma soluçando aflita;

Em cada estrofe inspirado

Por uma dor infinita;

Triste adeus da campa à beira,

Ao berço os olhos volvendo,

Aos pais, que ficam gemendo,

Quase à minha vida inteira!

O navio deslizou nas ondas; os horizontes distenderam-se, e o infinito pairou no espaço.

De quanta poesia não se embebeu então esta alma de poeta nas longas noites silenciosas, veladas à tolda do navio, quando as inflexões monótonas da canção do marinheiro resvalavam pela flor das águas!

Contemplou a beleza dessa imensa solidão dos mares, frisados pelos ventos, enlevou-se na poesia melancólica desses belos luares, desvanecidos pela vasta dilatação dos horizontes, escutou graves e solenes os rumores profundos do oceano, perdidos no espaço como ecos da voz do Senhor.

Alguma vez também sentiu roçar-lhe às faces as asas negras da tormenta, aspirou o hálito ardente do temporal, viu as nuvens chocarem-se, e as ondas embaterem-se.

Compreendeu a sublimidade dessa luta tremenda travada entre o homem rei e a tempestade soberana, entre o poder da inteligência e a força dos elementos.

Mas Deus decide!... O marinheiro ajoelha.

Nesse momento de grave recolhimento, em face da eternidade, a prece santa destes homens rudes se ergue mudamente para o céu entre o fragor da tempestade, e vai acolher-se ao seio de Deus.

Foram as inspirações destas cenas majestosas que criaram o - Naufrágio -, essa triste peripécia de um drama heroico, escrita com tanto fogo e imaginação:
Voa um baixel destemido

Rasgando os seios do mar!

Desce aos abismos perdidos,

Sobe as nuvens a afrontar!

Leva solto, ao vento dado,

O seu livre pavilhão;

E na mezena encostado

Vai fumando, sossegado,

O seu fero capitão!

Sobranceiro crava ao largo

Os olhos em torvo olhar...

O sorriso triste, amargo,

Vem-lhe os lábios agitar.

Que pensamento profundo

Revolve na mente audaz?

Quando o raio furibundo

Rasga as entranhas do mundo,

Só ele parece em paz!

Oh! Que nos dirá o arcano

D'aquela muda altivez?

Só - no meio do oceano,

Sobre as tábuas de um convés!

Ruge o vento - o pego alteia,

Rebrame com mais furor!

A tempestade se ateia,

Raio a raio se encadeia,

E bate horror sobre horror!

No fragor da tempestade

Como és tremendo, Senhor!

Como avulta a majestade

Das iras do teu furor!

Venha o ímpio aqui, descrido

Duvidar do teu poder;

Quero vê-lo confundido,

E como o cedro abatido

No chão a face esconder!

Neste concerto gigante,

Dos elementos à voz,

Em rubras fitas, brilhante

O raio cruza veloz!

As negras ondas fervendo

Em tenebrosos caixões

Vão a mais e mais crescendo...

Manto d'espuma estendendo

Pelos líquidos vulcões!

Porém cresce a onda, alaga,

Forma dilúvios o mar,

Rebrame, morde-se, esmaga

Como serpente a silvar!

O raio brilha... já desce...

Sobre o baixel estalou,

Que todo, inteiro, estremece!!...

Pende ao lado, e desfalece

Como a águia, que tombou!... 
Cruza os braços o piloto;

E o capitão a sorrir

Apontando o mastro roto"

"De joelhos - descobrir!

Bradou com a voz cortada;

"De joelhos, homens meus!...

Vem a morte ali sentada,

Com a punição de Deus!...”

Correram tempos. O navio entrou a barra do Rio de Janeiro; o poeta pisou terras do desterro.

O sentimento de angústia que confrangeu esta alma, no momento em que se viu em terra estranha, sem família e sem amigos, verteu-se nesses versos, em que as saudades da pátria vão de mistura com as ricas harmonias de nossa terra: - Numa ilha americana.

Quanto sentimento e poesia há nessa exclamação pungente, nessa pergunta ansiosa, que expira tristemente no desengano de uma resposta!...

Onde irei, estrangeiro n'este solo, Buscar um peito que minh'alma entenda?

Sentado à sombras das palmeiras, triste, Eu sinto meus cabelos ondulando Ao sopro preguiçoso d'estas brisas! As ondas vêm quebrar no serro agreste Dos alcantis da praia solitária! As mágoas me recrescem c'o murmúrio D'este cântico eterno de tristeza; Meus prantos se confundem nos gemidos D'aragem que perpassa, e nos perfumes

Das boninas do oiteiro, enamoradas Do silêncio da noite e das estrelas! E o coração em pranto me pergunta: Onde irei, estrangeiro n'este solo, Buscar um peito, que minh'alma entenda?

Saudade! que me doeis, e que me punges

Dize-me tu, se ninguém pode dizer-me: Onde irei, estrangeiro n'este solo, Buscar um peito, que minh'alma entenda?

Quem há aí que não compreenda todo o fel e toda a amargura desta solidão de alma, que vê a vida agitar-selhe em torno, e se sente só? No bulício dos homens não há um eco para suas dores! Em todos esses corações estranhas não há uma palpitação que lhe responda ao arquejar do peito; e de tantos espíritos que se agitam, movidos por mil causas, nem uma ideia se escapa para vir acolher-se ao seu pensamento.
Debalde procura um seio para suas confidências, um amigo para compreendê-lo. Debalde!... O indiferentismo o envolve como um círculo de ferro, de encontro ao qual a alma cheia de seiva e vigor vem quebrar-se e refranger-se, contraindo-se num desengano atroz, balbuciado nesta única palavra - Ninguém!

Ninguém!.. Que sublime poema de dores não há nesta simples palavra! E o peito sem desafogo, a tristeza sem consolo, o sofrimento sem alívio, a alma sem crenças e a consciência torturada que mente, recalcando no seio d'alma todas as aspirações dessa alma vigorosa.

Toda a sublimidade dessa poesia, tão profundamente sentida, é ter sido fielmente copiada. A imaginação escureceu-se para dar o desabafo às dores comprimidas por tanto tempo. Se não é a mais bela poesia deste livro e a mais rica de imagens, é de certo a mais íntima e repassada de sentimento.

Quem sou eu? Fantasma errante

Em solitário penar!

Vaga sombra vacilante,

Que aparece n'um instante

Para nunca mais voltar!

(Contínua)

\section{$* * *$ \\ Dores e Flores \\ Poesias do Sr. A. E. Zaluar ${ }^{19}$ \\ (Continuação)}

Ao abalo das grandes dores sucede sempre um desalento, uma inanição cheia de tédio e desgosto. É como um véu de gelo que encobre o coração e amortece-lhe a vida; é como uma sombra pálida e lutuosa que venda os olhos, e obriga-os a ver tudo por um prisma negro.

$\mathrm{Na}$ solidão e no isolamento, quando a natureza se harmoniza com este estado de alma, apenas se sente um desgosto sem causa, uma mágoa íntima, que o hábito torna a princípio suportável e depois quase necessários: de ordinário a relegam vem ungir com a santidade de suas preces esse martírio ignorado.

Quando porém a agitação exterior contrasta com essa letargia profunda da existência, vem o desengano, vem essa tristeza surda, sem consolações, porém sem desespero, que rói lentamente, fala de prantos e gemidos. As inspirações da natureza, os ecos dos prazeres do mundo, são como uma ironia amarga, porque apenas acordam n'alma a consciência de sua miséria.

É então que o homem se lança no prazer com ânsia e desespero: vai até a procurar emoções no meio das orgias, entre o vinho e o amor: o vinho é generoso, a mulher é bela; mas que importa se último trago é sempre de fel, e depois vem o tédio e o enjoo? Que importa, se no meio do gozo vem o esmorecimento da alma e o desencanto da vida?

${ }^{19}$ ALENCAR. José de. "Dores e Flores - Poesias do Sr. A. E. Zaluar". Correio Mercantil: Rio de Janeiro, 23 de agosto de 1851, n. 200, p. 2. 
Foi este desalento que o poeta reproduziu na sua Melancolia. É ainda uma das muitas poesias do livro que não se admiram, mas que se sentem. Em alguns de vossos momentos de alegres expansões concentrai-vos um instante, e lede esta poesia com recolhimento, e no fundo de vossa alma sentireis por força um sobressalto, um estremecimento de fibras, produzido pela expressão sentida destes versos. Será um pressentimento, o despertar de uma recordação extinta, ou talvez apenas uma impressão momentânea e passageira: porém o que quer que for vos revelará que nestas páginas não há somente palavras alinhadas e sílabas metrificadas, porém sim um ritmo natural, onde as sensações dolorosas da alma se reproduzem na expressão triste de uma mágoa profunda.

Quem és tu, que me acompanhas,

Triste, cismando a meu lado?

Quer no viso das montanhas,

Quer no silêncio do prado?

Toda de negro trajada;

No rosto pálido e triste

Uma rara sombra existe

De melancólica fada.

Se me assento pensativo,

No marco da solidão,

N'essas horas em que vivo

A vida do coração;

Em mil sonhos enleado,

Entre saudades tamanhas,

Quem és tu, que me acompanhas,

Triste, cismando a meu lado?

Se na mesa dos festins,

Entre fumo dos manjares,

Fervem líquidos rubins,

E dissolutos cantares;

Quando o espírito nas chamas

Arde ao lume das orgias,

E o remorso conta os dias;

Quem és tu, que então me chamas?

E depois:

Quem és tu, que me persegues

Nos ruidosos prazeres!

E na desdita me segues,

Sem nunca me conheceres?

Quer nas noites mal dormidas,

Que me ria - ou chore - ou cante,

Vejo-te sempre diante,

Nas mesmas sendas perdidas?

Até aqui falamos do sentimento: a existência parecia se haver concentrado nessa luta tenaz com uma dor acerba. Um dia porém o pensamento quebrou o letargo em que se envolvera, como numa crisálida, e deu largas às ideias que dormiam profundamente em seu seio.
Foi no cimo do monte da Gavia. Um tronco gigante de árvore morta se elevava só e isolado. Para o vulgar dos homens isso queria dizer apenas uma árvore seca; porém para o poeta havia ali uma ruína do passado em face das realidades do presente; havia uma página do grande livro da natureza, onde estava gravada em símbolos a história das vaidades humanas. Esse tronco gigante, rei das florestas, hoje morto, não exprimia o transunto dessas majestades feudais, cuja figura solene ainda se destaca altiva e soberana nas sombras do passado?

Este é o pensamento da poesia $O$ tronco isolado. Tudo ali revela a grandeza e sublimidade da ideia; o estilo já não tem a doce cadência dos versos ternos e sentimentais, o ritmo é forte e vigoroso como o exigiam as ideias que encadeia. Há nesta poesia algumas rimas sublimes, que só por si valem um título de poeta.

Em pé, despido - só, qual pensamento,

Que as humanas vaidades não procura;

Parece derrubada pelos tempos

Uma cruz de gigante sepultura!

Que tremenda lição tu não serias

Para os grandes do mundo - os potentados?

Hoje no fausto da grandeza erguidos,

No pó da terra em breve derrubados!

Quantas vezes, monarca da floresta,

A púrpura d'um manto se espedaça,

E da grandeza antiga apenas resta

O diadema d'espinhos da desgraça!

O último período desta vida de poetas é o repouso e a placidez que vem sempre depois das grandes crises. A alma serenada adormeceu placidamente no gozo de cantar alegrias.

Naturalmente a este tempo pertencem algumas ligeiras inspirações, alguns devaneios de imaginação, e muitas recordações da pátria, que justificam uma parte do título do livro Flores.

Algumas merecem de certo o nome: são flores na beleza das formas, na suavidade dos perfumes; outras porém desmentem o título: são dessas poesias sem espontaneidade, sem causa, dessas poesias que se fazem por pretexto e por força de vontade.

Não queremos com isso desmerecer o conceito do $\mathrm{Sr}$. Zaluar como poeta; sabemos que a alma tem seus momentos de esterilidade, e que esses pensamentos arrancados com esforço são filhos espúrios e sempre degenerados. Se alguma censura houvéssemos de fazer, não seria por certo ao poeta que compôs esses versos, mas ao escritor público que os julgou dignos de publicação. E por isso, em tributo à glória do Sr. Zaluar, arrancamos essas flores murchas à sua grinalda de poeta.

Agora só nos restam as últimas páginas do livro: o que aí está escrito não sei defini-lo. É uma alma partilhada entre saudade e remorso, que sente a necessidade suprema de ouvir o perdão balbuciado pelos lábios 
do pai. Uma infinidade de léguas separa o filho que implora e o pai que espera.

Era pois necessário esse grito anelante e convulso, essa prece angustiada e aflita, para devassar a distância e chegar ao coração do pai ainda úmida das lágrimas do filhos!

Não sei se todos verão com os mesmos olhos que eu. Quando leio esta poesia me parece que até nos sons das palavras sinto o eco de um pensamento oculto. Se o estilo pode materializar a ideia, é de certo nesta poesia que se realiza esta cristalização de pensamento, como lhe chama um belo escritor francês.

Vai, meu canto!... se as lágrimas que verto As letras apagar, com que és escrito, Balbucia-lhe um som, ergue-lhe um grito, A vida inteira lhe traduz n'um ai!

Há na rapidez destas frases uma aflição inexprimível; o pensamento anseia procurar uma palavra, um tom, uma frase que o exprima, que o traduza!... Porém há sensações íntimas, misteriosas e incompreensíveis que não tem nome na língua dos homens!

Daí essa ansiedade d'alma, percorrendo uma graduação de tons até partir-se num grito cortado e aflito.

Beija-lhe as plantas, curva-te humilhado, Exala-se em suspiros, chora!...oh! chora...
E como que sufocada pelas lágrimas, emudece um momento, e parece esperar:

Até que brilhe do perdão a aurora

Solene e grave em lágrimas de Pai!

Ao terminar estes ligeiros traços sobre o livro do Sr. Zaluar não julgamos necessário excitá-lo a publicar as suas outras produções, porque a sua consciência e o público que o julgou devem tê-lo firmado neste propósito.

ALENCAR

\section{Referências}

ALENCAR, José de. Ficção completa e outros escritos. Rio de Janeiro: Nova Aguilar, 1958. v. 1.

MENEZES, Raimundo de. José de Alencar: literato e político. Rio de Janeiro: Livros Técnicos Científicos, 1977.

SILVA, Inocêncio Francisco da. Dicionário Bibliográfico Português, Lisboa: Imprensa Nacional, 1860, tomo V.

ZALUAR, Augusto Emilio. Dores e flores. Rio de Janeiro: Tipografia de F. de Paula Brito, 1851.

Recebido: 11 de setembro de 2015 Aprovado: 23 de novembro de 2015 Contato:willjm@uol.com.br 